\title{
Green Buildings: The Future
}

\author{
${ }^{*}$ Varinder Hans ${ }^{1}$, Jaswinder Singh ${ }^{2}$ \\ ${ }^{1}$ University of Alberta, Edminton, Canada \\ ${ }^{2}$ Guru Nanak Dev Engineering College, Ludhiana,India \\ Corresponding author: "Varinder Hans
}

ABSTRACT: Due to increase in green house gas emission and increasing climatic changes, the building architecture needs to change to keep up with the time. Green buildings are the future buildings. They utilize natural resources for their energy needs and do not put burden on conventional sources of energy. These are resource efficient buildings from the design stage to the final building. In the present context a number of codes have been developed which need to be followed if a building is to be classified as green building. This paper is an attempt to find out the basics of green building and the codes to be followed to construct the green building.

Date of Submission: $10-07-2017$

Date of acceptance: 31-07-2017

\section{INTRODUCTION}

The world has been witnessing a plethora of weather changes. This has drawn the attention of all towards the factors that contribute to the changes in weather. Buildings we live in consume a lot of energy which is contributing towards the degradation of environment. Also we are consuming the non renewable resources of energy for our energy needs. To limit the use of the non renewable conventional sources of energy in buildings, the concept of green buildings was initiated. According to Wikipedia "Green building (also known as green construction or sustainable building) refers to both a structure and the application of processes that are environmentally responsible and resource-efficient throughout a building's life-cycle: from planning to design, construction, operation, maintenance, renovation, and demolition." This requires close cooperation of the contractor, the architects, the engineers, and the client at all project stages. The Green Building practice expands and complements the classical building design concerns of economy, utility, durability, and comfort.

Green buildings are supposed to be using all resources properly and efficiently. This includes water and energy. They are also required to ensure the health of occupants by providing them proper environment. They also aim at reducing waste, pollution and environment degradation. Natural materials are preferred for construction of green buildings rather than man-made materials. Green buildings are supposed to be sustainable buildings. The ideal green building would be a building project that would allow you to preserve most of the natural environment around the project site, while still being able to produce a building that is going to serve a purpose. The construction and operation will promote a healthy environment for all involved, and it will not disrupt the land, water, resources and energy in and around the building. This is the actual definition of a green building.

The U.S. EPA says "Green building is the practice of creating structures and using processes that are environmentally responsible and resourceefficient throughout a building's life-cycle from citing to design, construction, operation, maintenance, renovation and deconstruction. This practice expands and complements the classical building design concerns of economy, utility, durability, and comfort. Green building is also known as a sustainable or high performance building."

Sustainable or "green" building design and construction is a method of wisely using resources to create high-quality, healthier and more energy-efficient homes and commercial buildings. A green building is more than the sum of its parts - its process and impacts matter, too.

\section{Benefits of Green Building}

With new technologies constantly being developed to complement current practices in creating greener structures, the benefits of green building can range from environmental to economic to social. By adopting greener practices, we can take maximum advantage of environmental and economic performance. Green construction methods when integrated while design and construction provide most significant benefits. Benefits of green building include: 


\section{Environmental Benefits:}

- Reduce wastage of water

- Conserve natural resources

\section{Economic Benefits:}

- Reduce operating costs

- Improve occupant productivity

- Create market for green product and services

\section{Social Benefits:}

- Improve quality of life

- Minimize strain on local infrastructure

- Improve occupant health and comfort

\section{Green Building Codes}

A standard is a set of guidelines and criteria against which a product can be judged. Common standards related to building practices are created through consensus processes by organizations such as ANSI, ASTM, or ASHRAE. Supporting the governance of standards and certifications is the International Standards Organization (ISO), which defines and develops worldwide standards that frequently become law or form the basis of industry norms. ISO defines a standard as: "a document, established by consensus, approved by a recognized body that provides for common and repeated use as rules, guidelines, or characteristics for activities or their results." Codes come in two basic formats: prescriptive and performance, with outcome-based becoming a developing third option. A

Prescriptive path is a fast, definitive, and conservative approach to code compliance. Materials and equipment must meet a certain levels of stringency, which are quantified in tables.

Performance-based codes are designed to achieve particular results, rather than meeting prescribed requirements for individual building components.

Outcome-based codes for example, establish a target energy use level and provide for measurement and reporting of energy use to assure that the completed building performs at the established level. The unique difference between codes and building rating systems is that codes are mandatory. If green codes become adopted on a wide spread basis, their impact can change the building environment rapidly and extensively. The first codes for green buildings were laid down by Leadership in Energy and Environmental Design LEED.

Green building codes go beyond minimum code requirements, raising the bar for
- Improve air and water quality

- Protect biodiversity and ecosystems

energy efficiency. They can serve as a proving ground for future standards, and incorporate elements beyond the scope of the model energy codes, such as water and resource efficiency. The international code council formulated 2012 International Green construction code. The $\mathrm{IgCC}$ is the first model code to include sustainability measures for the entire construction project and its site - from design through construction, certificate of occupancy and beyond. This code gives baseline requirements, economic benefits, professional development and technical support. The code is adaptable, enforceable and consensus based. This code integrates with other international codes to develop sustainable buildings.

The California Green Building Standards Code (CALGreen Code) is Part 11 of the California Building Standards Code and was the first statewide "green" building code in the US. CAL Green is designed to save water and promote environmentally responsible, cost-effective, healthier places to live and work. The purpose of CALGreen is to improve public health, safety and general welfare by enhancing the design and construction of buildings through the use of building concepts having a reduced negative impact or positive environmental impact and encouraging sustainable construction practices in the following categories:

- Planning and design

- Energy efficiency

- Water efficiency and conservation

- Material conservation and resource efficiency

- Environmental quality

Likewise many other countries in the world have developed their own green building codes according to the climatic zones they fall in. For example Australia, Philippines, India all have their own set of green building codes. In some countries it is becoming mandatory for new commercial buildings to be constructed according to the green building code prevailing in the country.

\section{CONCLUSION}

Green buildings are the need of the hour and call of the future. Buildings need be made following the green building codes so as to make them sustainable and help preservation of environment for future generations. 


\section{REFERENCES}

[1]. Dr Shivraj Dhaka (14 July 2016). IGBC. https://igbc.in/igbc/redirect.html.

[2]. "Energy-efficient buildings - a business case for India? An analysis of incremental costs for four building projects of the EnergyEfficient Homes Programme". 80.82), NASA, Ads, Researcher Id Thomson Reuters, DOAJ.

Varinder Hans. "Green Buildings: The Future." International Journal of Engineering Research and Applications (IJERA) 7.7 (2017): 07-09. 